Revista Iberoamericana. Vol. LXV, Núms. 188-189, Julio-Diciembre 1999; 649-669

\title{
HIBRIDEZ CULTURAL/AFRICANÍA RELIGIOSA EN EL URUGUAY
}

\author{
POR \\ Juanamaría Cordones-Cook \\ University of Missouri-Columbia
}

If there is a lesson in the broad shape of this circulation of cultures, it is surely that we are all already contaminated by each each other...

Kwame Anthony Appiah

Desde los siglos XVI y XVII, la sed de riqueza y control del colonizador europeo ha estado condicionada por la convicción de la inferioridad del otro no-blanco. La lógica de la hegemonía colonial ha procurado fundamentar, justificar y legitimar el racismo, los prejuicios y la xenofobia ancestral. Desde entonces se han conceptualizado y racionalizado nociones ortodoxas verticales y rígidas de purezay origen. Las respuestas a ese autoritarismo cubren una gama que va desde la aceptación y el silencio a la articulación de mecanismos alternativos de reelaboración cultural y resistencia (Moraña 107-118) tales como la hibridación.

A pesar del impulso diferenciador y universalizante del poder hegemónico, debido al contacto de diferentes grupos raciales y a la porosidad de las fronteras culturales, el ideal europeo de raza y cultura pura e inmaculada no pudo sobrevivir.' ${ }^{1}$ Desde los inicios, se produjo un maridaje al nivel de la praxis que fuey, aún en ciertos círculos, hoy es concebido denigratoriamente como signo de contaminación y degradación regresiva.

La historia de la humanidad se desarrolla en torno al encuentro de diferentes culturas. La cultura constituye un sistema de símbolos, valores, patrones de pensamiento y de conducta heredados que operan como mediadores entre los individuos y su entorno para procesar y organizar los signos que encuentran. ${ }^{2}$ Por medio de este sistema, los individuos se desarrollan, transmiten y perpetúan sus conocimientos y actitudes sobre la vida y el mundo.

Los pueblos obligados a transmigrar traen consigo un bagaje cultural de costumbres, lenguaje, leyendas, ideas, valores y religiones. Al encontrarse diferentes pueblos y culturas, se produce un maridaje que se ha denominado al nivel biológico, hibridación, al nivel

\footnotetext{
' En The Birth of African-American Culture: An Anthropogical perspective, Sidney W. Mintz y Richard Price indican que esa interpenetración presenta uno de los planteamientos más importantes de la sociedad criolla/creole (5).

${ }^{2} \mathrm{Mi}$ conceptualización de cultura es informada por el pensamiento de Juri M.Lotman, en The Universe of the Mind.
} 
cultural, transculturación ${ }^{3} \mathrm{y}$, en cuanto al religioso, sincretismo. Proveniente de las ciencias biológicas, la noción de hibridación se refería a la cruza de animales pertenecientes a diferentes especies. Durante el siglo XIX, el término, aplicado a los seres humanos, implicaba una amalgama de diversas razas. En una jerarquía racial, primero estaba el indio, luego llegó el africano con sus descendientes a ocupar el escalón más bajo de la familia humana junto a los simios. Se estimaba que los africanos estaban destinados a servir a las razas superiores por pertenecer a otra inferior y que debían ser tratados como animales domesticados. Cuando Darwin, en The Origin of Species, llegó a la conclusión de que no habían diferencias esenciales entre las especies y sus variantes, se sustituyó la idea de animalización por la de corrupción del original puro pues la mezcla constituía una amenaza al vigor y la pureza racial (Young 1-28).

En la última década, uno de los hitos del debate cultural ha sido la hibridación, extendida metafóricamente a la cultura. Es una noción fundamental para comprender la sociedad latinoamericana contemporánea constituida por aluviones de razas, etnias y culturas, con múltiples y móviles identidades individuales y colectivas. ${ }^{4}$

El abrazo de dos o más culturas activa un diálogo transitivo de matrices culturales diferentes, contradictorias a veces. Con mecanismos psíquicos de proyección e introyección, la cópula cultural yuxtapone espacios y temporalidades y promueve la interacción de ideas y cosmovisiones dinamizando un proceso de influencia recíproca. Ese diálogo se entabla en lo que Renato Rosaldo designara espacios de invisibilidad cultural, zonas culturales fronterizas de encuentro del discurso hegemónico con el subalterno (77-88). Con una heteroglosia lúdica e incesante, este último proyectay traduce sobre los códigos hegemónicos una cosmovisión periférica que funciona como resistencia a los paradigmas conceptuales dominantes.

De acuerdo a Michel de Certeau, en The Practice of Everyday Life, el subalterno encuentra en su diario vivir modos de adaptar los sistemas culturales que le son impuestos. Emplea una técnica de camuflaje: aparentemente acepta las leyes y prácticas de representación hegemónica pero las dirige a fines diferentes de los perseguidos por el orden dominante (2932). Sin rechazarlas ni transformarlas abiertamente, absorbe el empuje dominante y lo altera subvirtiéndolo desde su interior. Recurriendo a tácticas de selección, adaptación y adopción, entreteje las diferentes tradiciones a su alcance y metaforiza el orden dominante en un registro diferente. En el proceso, van operando elementos de manipulación y/o engaño característicos de la resistencia de aquellos a quienes se les niega un espacio propio necesario para sobrevivir dentro de una red de representaciones y fuerzas hegemónicas limitantes y opresivas (de Certeau 18). El marginado permanece dentro del sistema que ha asimilado y que lo asimila externamente siendo siempre el Otro, pero sin abandonar

\footnotetext{
${ }^{3}$ Fernando Ortiz acuñó el término transculturación para reemplazar "aculturación", de la academia de los Estados Unidos. Por transculturación, entendía una neo-cultura, una nueva realidad surgida de ese tráfico intercultural que, con un ethos igualitario, no privilegiaba ni el poder hegemónico del colonizador ni el del desplazado colonizado. Más tarde Nancy Morejón, en Nación y mestizaje en Nicolás Guillén, y Angel Rama, en Transculturación narrativa en América Latina, han elaborado este concepto seguidos de toda una pléyade de críticos y teóricos latinoamericanos contemporáneos. ${ }^{4}$ Para un desarrollo de estas implicaciones en la conceptualización de hibridación, consúltese a Robert J.C. Young (4).
} 
totalmente el sistema al que se ha visto obligado a renunciar exteriormente. Creativamente resiste su papel cultural pasivo y constituye un espacio propio entre los intersticios del poder hegemónico.

En el proceso, se producen rupturas de códigos y se plantean desafíos entre las fronteras discursivas y culturales que van desplazando perspectivas, territorios y fronteras sociales, económicas, políticas y estéticas. Con un efecto generativo de transformación social, ${ }^{5}$ la hibridez establece nuevas formas de representación, de signos y símbolos. Transforma el entorno semiótico. ${ }^{6}$ En el contacto ni el dominador ni el dominado se libran de algún tipo de contaminación, pero no llegan a resolver la tensión entre las polaridades conceptuales.

El efecto del proceso de hibridación no consiste en rescatar al subalterno sino en desequilibrar y descentrar el factor hegemónico creando nuevos espacios y nuevas formas de poder, de saber y de ser. La hibridación produce un contradiscurso que tiene efecto de resistencia y antídoto contra el esencialismo, la univocidad y el control cultural, a la vez que pone de manifiesto la vitalidad de los grupos marginados. ${ }^{7}$

En su misión civilizadora, la autoridad colonial en América había impuesto junto con el orden civil, el cristianismo. Había establecido universal y coercitivamente una tradición monocultural con la Biblia como mito normalizador y significante de autoridad. (Bhabha 166). Al enfrentarse a la evangelización, para sobrevivir y no desaparecer, el africano en América se había refugiado en los lugares comunes con el catolicismo en una mímica que no duplicaba una esencia sino una apariencia pues no renunciaba totalmente a sus propios dioses. Los mantenía camuflados bajo las imágenes de los santos católicos. Durante mucho tiempo la única libertad que gozaban los esclavos era la espiritual, encubierta por la máscara de aceptación de los cánones cristianos. ${ }^{8}$

En las instancias de deculturación más intensa, la adopción del cristianismo fue más sustantiva. Sin embargo, los elementos culturales reprimidos de la conciencia colectiva no desaparecían totalmente y algunos eventualmente regresaban transformados. En el caso uruguayo, por su historia de represión y asimilación cultural, el afro ha sufrido una intensa deculturación, proceso que paulatinamente se ha venido revirtiendo con una escalada meteórica en el ámbito religioso durante los últimos diez años.

\footnotetext{
${ }^{5}$ Para conceptos sobre la hibridación en la colonia relacionados con los efectos generativos, véase: "Tracing Hybridity in Theory," de Nikos Papastergiadis.

${ }^{6}$ Estamos aludiendo a la transformación de la semiósfera mencionada por Juri L. Lotman (123).

${ }^{7}$ Un caso de hibridación e inscripción de un contradiscurso se manifiesta en América con los indígenas que constituían la mano de obra más barata durante el período barroco y churriguresco. Se las ingeniaban para inscribir camuflados en las construciones elementos de su propia cultura y de la fauna y flora autóctona americana.

${ }^{8}$ Para una elaboración más extensa del empleo de la máscara por el colonizado, véase: "The Negro and Psychopatholgy," en Black Skins, White Masks, de Franz Fanon, y en referencia a la aceptación religiosa de parte del subalterno, véase de Certeau (31). La antropóloga urguaya Mónica Olaso afirmaba, en una entrevista realizada el 19 de junio de 1998 en Montevideo, que los esclavos africanos llegaban a colocar dentro de las esculturas que representaban a los santos católicos una imagen del orixá con el cual se había sincretizado ese santo en particular.
} 


\section{Africania uruguaya}

Más allá del Río de la Plata la africanía racial y cultural uruguaya es prácticamente ignorada." Sin embargo, la presencia africana en lo que constituía la Banda Oriental, denominación colonial del territorio al este del río Uruguay, se remonta a 1680, año de la fundación de la Colonia del Sacramento, primer asentamiento europeo en esa zona, que más tarde se habría de convertir en centro negrero. Una vez fundada la ciudad de Montevideo (1726), alegando escasez de mano de obra, el Cabildo solicitó autorización para comenzar la importación de esclavos. En 1743, llegó el primer embarque legal de africanos. Cincuenta años después, Montevideo fue declarada único puerto de entrada y distribución de esclavos para el virreinato del Río de la Plata, extendiéndose a los territorios actuales de Chile y Perú. Los esclavos que entraban a Montevideo provenían de diversas áreas de África y eran comercializados y distribuidos en otras zonas del virreinato. Los que habían de permanecer en el territorio, provenientes de Bahía y Río de Janeiro, ingresaban a la Banda Oriental por la frontera abierta del norte con la colonia portuguesa. Llegaban habiendo sufrido ya en África diferentes grados de hibridación entre otras culturas africanas, y, en América, con los portugueses y los indios aborígenes del territorio lucitano.

En la Banda Oriental, bajo un régimen de relativa benevolencia, los esclavos soportaban las injusticias y los abusos propios del sistema. Cuando la esclavitud fue totalmente abolida en 1853 , los descendientes de africanos entraron a una sociedad teóricamente abierta con posibilidades educativas y laborales que, debido a una legislación crecientemente liberal, potenciaba la movilidad vertical. En la práctica, su situación era y continuó siendo muy precaria. Con pequeñas variantes y desde siempre, los afro-uruguayos han integrado, los estratos sociales inferiores que los relegan a la periferia social abundante en restricciones tácitas. ${ }^{10}$ Sus antiguos amos nunca les dejaron olvidar su situación de inferioridad.

Pero aún en ese clima, los descendientes de africanos participaron en la formación de la nacionalidad y pusieron su fuerza creadora y vital al servicio de la sociedad con valiosos aportes culturales. Los afro-uruguayos se sienten tan uruguayos como cualquier otro hijo del país y se identifican con la nación. Sin embargo aún no han tenido ni espacio ni instancia que les permita ser agentes de su propia historia. Inconscientemente imbuidos de la mentalidad colonial, los afro-uruguayos deseosos de asimilarse al caucásico frecuentemente han adoptado un papel pasivo y se identifican culturalmente con el resto de la sociedad uruguaya encarnando así al subalterno absorbido por el sistema cultural hegemónico que lo subestima.

Por otra parte, el uruguayo medio se autodefine y hace alarde de europeísmo y homogeneidad étnica. Respondiendo a una doxa colectiva de largo arraigo; aún cuando es consciente del componente africano de la población, lo ignora. Como consecuencia de una

\footnotetext{
${ }^{9}$ El porcentaje de africanos en su época culminante durante la colonia fue de un 26 a un $30 \%$. En el momento actual queda aproximadamente un $4 \%$ de sus descendientes identificados exclusivamente como afro-uruguayos en base a rasgos fenotípicos. Sin embargo como resultado de la misceginación, en el Uruguay hay un número indeterminado de mulatos/pardos.

${ }^{10}$ Parte de esta información se origina en el Capituo I de ¿Teatro negro uruguayo? Texto y contexto del teatro afro-uruguayo de Andrés Castillo, de Cordones-Cook.
} 
mentalidad colonizada aún no extirpada y siempre latente, las relaciones interraciales en el Uruguay están marcadas por un eurocentrismo común en las naciones americanas. Desde los albores de la Ilustración con Hume y Kant, los europeos y sus descendientes han estado imbuidos de un racismo ancestral con actitudes que asocian al afro con los seres más inferiores y lo encuentran repulsivo frente al angelical caucásico. La representación del afro creada por el europeo y sostenida por el español, quien privilegia la importancia de la pureza de la sangre, goza de más permanencia que cambio, con lo cual contribuye a perpetuar la situación discriminadora.

A pesar de sus contribuciones a la formación de la nación y a la cultura popular urbana, en su trayectoria cultural e histórica el afro-uruguayo ha pemanecido marginado. Hasta nuestros días, vive en una situación de alienación, subalternización y exclusión de las oportunidades sociales, culturales y laborales, de las fuentes de poder, y, por supuesto, de todo tipo de reconocimiento que no sea la benevolencia y tolerancia del caucásico. Esa tolerancia está teñida de una condescendencia y subestimación en cuya raíz subyace un paternalismo racista benevolente ${ }^{\prime \prime}$ que infantiliza, ridiculiza y finalmente denigra al afrouruguayo llegando a hacerlo invisible. ${ }^{12}$ De modo que dentro de un contexto social eurocéntrico donde la normatividad universalizadora está fundada y controlada por el caucásico, el afro con su cultura, sus preocupaciones y problemática particular, permanece en la oscuridad de la periferia.

Paradójicamente, el uruguayo ha buscado institucionalmente erradicar las desigualdades e injusticias sociales. En defensa de los derechos humanos, se ha adherido tradicionalmente a un ethos democrático, igualitario y libertario que está inscrito en el sistema legislativo a partir la constitución de la República. Abrazando este mito y persuadido de su universalidad, el uruguayo se resiste a admitir o aceptar la existencia de ningún tipo de discriminación. Desde el momento del ingreso de los africanos al suelo oriental (uruguayo), sus relaciones con los caucásicos fueron reguladas por jerarquías piramidales maniqueas y excluyentes. El uruguayo no reconoce el delirio maniqueo que casi ancestralmente informa y configura la difusa y no verbalizada normatividad de su doxa. El delirio maniqueo, según Franz Fanon en The Wretched of the Earth, caracteriza la mentalidad colonial. Adjudica a un nivel moral, intelectual y socio-cultural, la superioridad, la razón, la cultura y la civilización al colonizador/blanco, y la inferioridad, el instinto, la naturaleza y la barbarie, al colonizado/ afro con quien asocia imágenes de impureza y contaminación. ${ }^{13}$

En el Uruguay, se da un doble discurso: el legal, por un lado, y, por otro, el de la praxis, generado por el habitus, o sea el sistema de disposiciones duraderas y trasponibles que

\footnotetext{
"Como ejemplo de esa benevolencia y condescendencia, léase Cosas de negros, de Vicente Rossi, obra que a pesar de presentar estudios pioneros en varios aspectos de la cultura afro, desde el título mismo revela una tácita subestimación hacia ese grupo étnico.

${ }^{12}$ En cuanto a estos aspectos del racismo, véase el capítulo I de Black Skin, White Masks, de Franz Fanon.

${ }^{13}$ Para un desarrollo lúcido y contemporáneo de la proyección de esa polaridad blanco/negro en metáforas socio-culturales, véanse "The Economy of the Manichean Allegory: The Function of Racial Difference in Colonialist Literature" y Manichean Aesthetics: The Politics of Literature in Colonial Africa, de Abdul R. JanMohamed.
} 
funciona como matriz de percepción y acción del individuo. ${ }^{14}$ El habitus del uruguayo medio está permeado de un determinismo racial esencialista que revela y perpetúa los estereotipos negativos del afro.

Durante siglos y en oleadas sucesivas, el africano fue transplantado forzadamente a América. Los europeos habían venido voluntariamente plenos de ambiciones e ímpetu realizador para ser amos de tierras e individuos. Por su parte los esclavos, agobiados y tratados como bestias de trabajo, para sobrevivir, operaban defensivamente con disimulo y, de acuerdo a las circunstancias, se adaptaban a la nueva cultura.

Su relación con el amo blanco fue de víctima/opresor. El amo sin consideraciones humanas ni morales arrancó al africano de raíz de su cultura madre. El europeo creía poseer el cetro de la verdad y la imponía sobre la conciencia del esclavo quien, sin otras alternativas, retrocedía, se sometía, y quedaba en silencio. Para el blanco, el cuerpo afro valía sólamente como bien de trabajo. Su mente era anulada, o sea que, metafóricamente se le decapitaba.

En un proceso inherente a la explotación colonial y neo-colonial, ${ }^{15} \mathrm{el}$ amo desmantelaba la identidad original del afro y le devolvía una imagen negativa y distorsionada. Arrancado de la experiencia de totalidad y plenitud en su cultura/madre donde su identidad era confirmada, el africano fue víctima de una castración cultural. ${ }^{16}$ Entraba a un nuevo orden social marcado por una carencia primordial, la de un paraíso perdido.

La intensidad de ese asalto cultural dependía de las circunstancias propias de la economía local, del empleo específico de la mano de obra esclava, ya fuera en agricultura, ganadería, minería, artesanía o servicio doméstico. ${ }^{17}$ En Uruguay, no se dio una economía de plantación como en Brasil o en el Caribe donde los esclavos trabajaban juntos y convivían en habitaciones en común, lo cual permitía el cultivo secreto de tradiciones compartidas. En Uruguay, el esclavo raramente era empleado en trabajos camperos, trabajaba en pequeños grupos de menos de diez individuos en el servicio doméstico y convivía con sus amos. Debido a estas circunstancias el africano allí, sufrió un proceso de deculturación más radical que en otros países. ${ }^{18}$ Perdido el vínculo con su cultura y su historia, eclipsó de su memoria sus propios medios de expresión, su ethos, su cultura, aunque no total ni definitivamente.

Sin embargo, la trayectoria cultural afro-uruguaya no ha sido sólo de pérdida, ruptura y discontinuidad. A pesar de la deculturación sufrida, en su fuero íntimo el afro-uruguayo

\footnotetext{
${ }^{14}$ De acuerdo a Pierre Bourdieu, el habitus constituye una clasificación internalizada de esquemas mentales y corporales que fungen como matriz simbólica las actividades prácticas, conductas, pensamientos y juicios de los individuos actuando en sociedad (Bourdieu; Wacquant 17-18).

${ }^{15}$ Para un desarrollo más amplio del tema, consúltese "Aportes culturales y deculturación", de Manuel Moreno Fraginals.

${ }^{16}$ Para una explicación lacaniana de la castración cultural sufrida por los esclavos africanos, véase "Desafricanización", en ¿Teatro negro uruguayo? Texto y contexto del teatro afro-uruguayo de Andrés Castillo (Cordones-Cook 15-18).

${ }^{17}$ Sobre el impacto de la economía en la deculturación del esclavo, véanse Los afro-uruguayos, de Carlos Rama (16-17), ¿Teatro negro uruguayo? Texto y contexto del teatroafro-uruguayo de Andrés Castillo, de Cordones-Cook (17), y El candombe: Sus orígenes, su historia, sus proyecciones, de Tomás Olivera Chirimini y Juan Antonio Varese (3-4).

${ }^{18}$ Como otros estudiosos del tema, Abril Trigo sostiene que si los afro-uruguayos hubieran sido segregados y hubieran convivido en grandes grupos como en otros países, podrían haber desarrollado y cultivado una cultura menor (719).
} 
conservó elementos africanos que como las represiones de la conciencia, pujarían por reaflorar en fluctuaciones de recuperación y renovación. Tales empujes se han manifestado en esfuerzos de rescate de elementos culturales africanos con la fundación de órganos de prensa afro y de organizaciones sociales y culturales y el surgimiento de valores intelectuales en diferentes momentos de este siglo. El momento de oro de la intelectualidad afro-uruguaya se dio durante la década de los treinta y parte de los cuarenta, período que coincide con los años de gran dinamismo y desarrollo intelectual en toda la diáspora africana, en Estados Unidos, el Renacimiento Negro de Harlem, con escritores de la talla de Langston Hughes y W.E.B. Dubois, Nicolás Guillén en Cuba, Juan Pablo Sojo en Venezuela. Todos buscaban recuperar y afirmar su africanía, su historia y su cultura mientras que se liberaban de los estereotipos y del estigma que los había plagado.

En el Uruguay, los intelectuales afro se nuclearon alrededor del periódico Nuestra Raza, fundado en 1917, primera época que durará hasta diciembre de ese año. Luego continuó en su segunda época con mayor brío desde 1933 a 1950, liderado por Pilar y Ventura Barrios, Elemo Cabral, Lino Suárez Peña e Isabelino José Gares. De ese núcleo surgió la inciativa del Partido Autónomo Negro que infructuosamente incursionara en el territorio político y que hubiera de disolverse por falta de apoyo entre los propios corrazáneos. $^{19}$

Nuestra Raza, inspirado por su lema "De la raza, por la raza y para la raza", apoyaba las iniciativas hacia la erradicación de estereotipos y prejuicios contra los afro, el mejoramiento de sus condiciones socio-culturales así como la promoción de solidaridad racial, poco evidente aún hoy en día. Además, operaba como órgano de difusión cultural. Publicaba poesía, narrativa y teatro afro-uruguayo, ya fueran textos breves, comentarios, reseñas o noticias de representaciones teatrales. En ese momento hubo una considerable actividad de teatro popular afro en Montevideo con obras de Isabelino José Gares, de Roberto Cisneros, de Carlos Cardozo Ferreira, y representaciones de cuadros filodramáticos de autor anónimo.

Los intelectuales afro-uruguayos mancomunados alrededor de Nuestra Raza constituyeron una minoría que no se extendió hacia todos los corrazáneos. Cuando desapareció esta generación, se produjo un gran vacío intelectual entre los afro en Montevideo. A fines de los años cincuenta, Francisco Merino intentó llenar ese hiato. Creó el Teatro Negro Independiente de Montevideo. ${ }^{20}$ Promoviendo el rescate de auténticos valores africanos en vías de desaparición, Merino aspiraba a desarrollar una expresión dramática auténticamente afro-uruguaya. Con aliento netamente popular, postulaba múltiples objetivos sociales: conducir al afro-uruguayo hacia la superación personal, socioeconómica y cultural, y hacia una cohesión comunitaria que, en pos de un espacio social digno, lo encauzara más allá de la indigencia y la marginación. Lamentablemente, los enaltecedores planteos que impulsaron la iniciativa de Merino fueron escasamente logrados. Cuando Merino falleció en 1982, el Teatro Negro Independiente, falto de líder, de recursos

\footnotetext{
${ }^{19}$ Interesa recordar que en la misma década se estaba produciendo un fenómeno similar en Brasil. Se había fundado un partido político afro-brasileño que en poco tiempo se desmanteló.

${ }^{20}$ Para una historia de ese teatro, consúltese "El Teatro Negro Independiente" (Cordones-Cook 3239).
} 
económicos y del respaldo de una comunidad unida, se desintegró concluyendo un momento único para la africanía y el teatro uruguayo. ${ }^{21}$

En pos y en defensa de la africanía, se han fundado varias organizaciones negras en Montevideo. Desde 1941, funciona la “Asociación Cultural y Social Uruguay” (A.C.S.U.) que promueve el rescate de tradiciones africanas, la unión y cooperación de los afrouruguayos, además de actividades sociales y culturales. En 1954, Manuel Villa organizó la "Sociedad Amigos de África en el Uruguay" que publica el periódico Bahia Hulan-Yack, órgano de denuncia de la discriminación y de difusión de la cultura de la diáspora africana.

En los últimos quince años se observan en Uruguay otros empujes reafricanizadores. Están surgiendo nuevos valores literarios, particularmente en poesía con Cristina Rodríguez Cabral, Tamara de la Cruz, Agapito Carrizo y Jorge Emilio Cardoso, quien también ha incursionado en otros géneros..$^{22}$ En 1987, se fundó la Organización Mundo Afro que, con ambiciosos objetivos educativos y de investigación en artes y letras, incentiva estudios sobre el protagonismo afro en el Uruguay así como proyectos de desarrollo y cooperativismo. Provee varios servicios sociales que atrae estudiantes afro que están empezando a ocupar las aulas universitarias. Convoca seminarios y otras actividades culturales para auspiciar la valoración de la identidad afro-uruguaya. Además, la organización tiene una casa editorial que divulga la literatura afro y estudios sobre la experiencia africana en el Uruguay y publica un periódico: Mundo Afro, foro de crítica y reflexión.

\section{Africanización Religiosa}

Las culturas africanas que llegaron a la Provincia Oriental desaparecieron como tales. No así algunas de sus tradiciones que sobrevivieron transformadas y adaptadas a otras formas culturales: la música, la danza, la comida, el lenguaje y la religión.

A pesar del canibalismo cultural sufrido, por su inherente vitalismo, los afrouruguayos se refugiaron en su música, danzas y ceremonias, y reelaboraron algunos elementos propios de su religiosidad. Arraigados en la cultura uruguaya y residualmente ocultos en el folclor, el candombe, danza de origen ritual afro-uruguaya, y la curandería, práctica curativa popular, revelan profundas huellas religiosas africanas.

De 1760 datan las primeras danzas públicas de las comparsas de esclavos en Montevideo quienes desfilaron en la procesión de Corpus Christi. Luego ante las protestas de otros participantes blancos, los africanos dejaron de desfilar. Sin embargo, les fue permitido reunirse los domingos y fiestas de guardar a extramuros de la ciudadela de Montevideo, sobre la costa, donde se entregaban a sus propios ritmos y ritos.

Durante la colonia, los afro-uruguayos se agruparon en naciones según el lugar de procedencia. Con el tiempo, se organizaron en cabildos que reflejarían los caracteres

${ }^{21}$ Del Teatro Negro Independiente sólo ha llegado hasta nosotros un excelente grupo de baile folclórico, "Bantú", bajo la dirección de uno de los miembros del elenco de Merino, Tomás Olivera Chirimini, y la participación de algunos de sus actores. Interesa señalar que, en Brasil y en la misma época, Abdias do Nascimento también había fundado un grupo de teatro afro-brasileño que tuvo corta vida, menos de dos décadas.

${ }^{22}$ Véanse las antologías de poesía afro-uruguaya contemporánea del Profesor Alberto Britos. 
culturales de las naciones. ${ }^{23}$ Ante el despojo cultural, el esclavo fue buscando satisfacciones ocultas. Encontró en los cabildos un espacio privado para el afianzamiento y difusión de algunas tradiciones religiosas y folclóricas secretas (Bottaro 519). Allí realizaban celebraciones que revelaban el vitalismo de las religiones africanas con sus rituales agrícolas, de iniciación o transición. Mientras que rendían culto a sus propias tradiciones y entidades sobrenaturales, iban aceptando y/o adaptando las creencias, los santos y el calendario de los festivales católicos, como el Día de Reyes de especial interés por el rey mago africano, Baltasar. ${ }^{24}$

En un principio en Montevideo, las celebraciones de los cabildos eran privadas. Luego esas sociedades africanas se fueron abriendo al público. Se volvieron más vulnerables a las influencias foráneas resultando en un blanqueamiento que aceleró la deculturación a la vez que el aliento de la cultura afro iba permeando la caucásica. En 1874, un grupo de jóvenes de la alta burguesía montevideana, se embetunaron y disfrazaron de lubolos con vestuario de esclavos para desfilar en carnaval bailando música africana y cantando en lenguaje bozal. Pocos años después los afro-montevideanos entraron a participar directamente en esos desfiles africanizando irreversiblemente el carnaval uruguayo.

La comparsa lubola siempre se ha organizado con personajes definidos que bailan el candombe. Procedente de danzas dramáticas religiosas de antiguos ritos bantúes que invocaban y suplicaban a los dioses africanos, esta danza fue asimilando algunos elementos del ritual católico así como figuras de la contradanza europea. Su apogeo fue entre 1875 y 1890, cuando empezó a perder algunas de sus características más acendramente africanas (Moro y Ramírez 26) para llegar hasta nuestros días convertido en un híbrido baile popular.

Fiesta popular originalmente europea, el carnaval les abrió a los afro un espacio propicio para la reactivación y reafirmación de elementos culturales propios que el poder hegemónico inferiorizaba. Los afro-uruguayos habían ido acaparando paulatinamente el carnaval y territorializando la cultura popular uruguaya para llegar hasta nuestros días a ser un componente fundamental. Componente que, de acuerdo a Abril Trigo, arriesgó su continuidad en la década de los 70 (716). Durante el Proceso militar uruguayo (1972-1984), la dictadura atacó toda manifestación popular que no se adhiriera a su ideología. ${ }^{25} \mathrm{El}$ candombe y otras expresiones afro fueron blanco de ese ataque. Sin embargo, bajo la autoridad panóptica del Proceso y desde su marginalidad, por entre los intersticios, los afrouruguayos continuaron ejerciendo su creatividad e integrando subrepticiamente elementos culturales negados dentro del discurso dominante.

\footnotetext{
${ }^{23}$ Los cabildos y las naciones mantenían vivas muchas de esas tradiciones haciendo así el proceso de deculturación más lento. En los países en que este tipo de organización subsistió como en Cuba y Brasil la desafricanización fue menos intensa que en Uruguay.

${ }^{24}$ Para una descripción extensa de las ceremonias y rituales afros en la colonia rioplatense, consúltense: Apuntes y datos referentes a la raza negra a los comienzos de su vida en esta parte del Plata, de Lino Suárez Peña y Cosas de negros, de Vicente Rossi.

${ }^{25}$ Además, durante ese período el estado hizo demoler los pocos edificios que, siendo joyas arquitectónicas, representaban la cultura afro con toda su miseria económica, tales como el conventillo Medio Mundo y el barrio Ansina, desplazando a sus habitantes a los cinturones de la ciudad (Trigo 722).
} 
Otra manifestación de cultura popular que lleva inscritas huellas religiosas africanas es la curandería, sistema alternativo que comparte espacios curativos con la medicina tradicional (Romero 15). ${ }^{26}$ Ejercida generalmente por mujeres de la periferia social, la curandería ${ }^{27}$ en Uruguay constituye una práctica de curación que conjuga lo somático y lo psíquico con creencias mágico-religiosas, lo cual le ha valido la marginación, la persecución y el escarnecimiento del poder hegemónico. Ello no ha obstado para que los propios médicos recomienden para ciertos males el tratamiento de una curandera. ${ }^{28}$ Descendiente de antiguas tradiciones etnográficas, españolas, indígenas y africanas, la curandera tiene acceso a fuerzas cósmicas invisibles pero vitales que facilitan el tratamiento ritual. Se trata de un ser transicional con capacidad de éxtasis que promueve el vuelo mágico para mediar entre lo profano y lo sagrado, y acceder a la esencia del mal (Porzecanski 107).

Durante la segunda mitad del siglo XX, la curandería ha empezado a compartir esa función curativa con las religiones afro-brasileñas que están ganando terreno en Uruguay. Entre sus prácticas, incluyen la curación de enfermedades tanto físicas como mentales, gracias a la capacidad del sacerdote de comunicarse con las entidades divinas y con los ancestros reveladores de misterios y conocimientos de carácter curativo. La función de dispensadora de salud contribuye al afianzamiento social y a la captación de adeptos para estas religiones, aunque es claro que la curación de males somáticos en el terreiro $^{29}$ no es la función central de sus sacerdotes como en el caso de las curanderas. Provenientes de todas las clases sociales, los consultantes y clientes acuden a estos templos buscando cura a todo tipo de dolencia, física o espiritual.

Las religiones afro-brasileñas fueron infiltrándose al Uruguay por la frontera norte con el Brasil, al principio clandestinamente en un contrabando cultural, reflejo y continuación del contrabando que desde siempre ha vinculado la economía de ambos países. Los uruguayos descubrieron como resultado de esa pacífica y silenciosa invasión, la magia de estas religiones, con sus teologías, rituales y prácticas, producto de una hibridación con elementos predominantemente africanos: Candomblé, Umbanda, Batuque y Quimbanda, estas dos últimas derivadas de la Macumba carioca. Candomblé es la religión afro de mayor arraigo en Brasil, mientras que Umbanda es la más difundida en Uruguay motivo por el cual concentraremos nuestra atención en esta última. ${ }^{30}$

No hay una forma singular de Umbanda (Brown 37). Se trata de una religión heterodoxa, flexible y dinámica que no se sustrae al influjo de las culturas con las cuales

${ }^{26}$ Además se practican otros sistemas medicinales alternativos, entre ellos la filoterapia y la herboristería, que están vinculados en algunos aspectos a la curandería y las religiones de origen africano.

${ }^{27}$ Sobre la curandería véanse: Porzecanski, Curanderos y canibales; Romero, "Antropóloga analiza"; Armando de Oxalá, "Brujos, científicos, medicina" y "Cuerpo, mente y espíritu: Dioses, salud y enfermedad".

${ }^{28}$ Me refiero específicamente a los casos de una eccema: la culebrilla.

${ }^{29}$ El terreiro o terreira, templo y lugar de consulta de las religiones afro-brasileñas, representa la hibridación religiosa con una iconografía que conjuga el catolicismo con la religión afro. Allí coexisten la virgen, el corazón de Jesús y otras imágenes de santos católicos con las de orixás, budas y diablos envueltos en aromas peculiares con música de tambores, bailes y canciones.

${ }^{30}$ En Montevideo, hay más de 2.000 terreiros de Umbanda y uno de Candomblé. 
se asocia. Las religiones del África Central y Occidental, de donde provenían la mayoría de los africanos traídos a América, frente a otras culturas se abrían con una actitud de adición y no de exclusión. Por otra parte, sus rituales se practican con constante improvisación según el momento y el contexto. Todo ello facilitaba y sigue facilitando la experimentación y adopción de nuevas prácticas culturales. De modo que, en el encuentro con las culturas locales, las religiones africanas se fueron adaptando a los contextos sociales reinterpretando y traduciendo elementos culturales propios y ajenos. Retenían fragmentos de continuidad del sistema místico-simbólico africano, mientras que adoptaban y aceptaban prácticas extranjeras, reformulando eventualmente la suya propia. La historia de Umbanda así como la de todas las religiones afro-americanas surge de una dialéctica de negociaciones y renegociaciones con camuflajes y máscaras. Es una historia de contrapunto, transformación e hibridación cultural generada por la necesidad de sobrevivir en un mundo hostil.

Con varios grados de intensidad, el sincretismo religioso se produjo en América como un bricolage. El afro-latinoamericano, escaso de recursos y con espíritu improvisador, combinó creativamente los materiales y recursos que encontró a su alcance para producir formas culturales que pudieran satisfacer sus necesidades. Según Michel de Certeau, el bricolage es una estrategia que emplea el marginado para crear una cultura propia de los remanentes del grupo dominante. Constituye una práctica de evasión y resistencia que cuando se refiere a una creación visual la hegemonía cultural designa artesanía y no arte (151) y cuando se aplica a las religiones afro-americanas, designa culto y no religión. ${ }^{31}$ Con ello se justifica y fortalece la arrogante subestimación de los blancos mientras que se despoja de valores trascendentales la cultura africana.

Iniciada en 1908 en Niteroi, Río de Janeiro, por Zelio Fernandez de Moraes, Umbanda surge del transplante y convivencia de diferentes pueblos y linajes religiosos: el africano, el católico, el amerindio, el kardecista, el islámico, el hinduísta y el budista. ${ }^{32}$ Siempre con predominio africano, esta religión amalgama los diferentes aportes culturales estableciendo un proceso dialéctico entre las cosmovisiones y los ethos de las diferentes etnias y culturas, densas en significación racial, social y política.

Para poder moverse en dos mundos, el europeo y el africano, el sagrado y el profano, y disimular su propio ritual, el esclavo tomó elementos de la liturgia, el culto y el santoral católico. Asimiló a los orixás, ${ }^{33}$ divinidades africanas menores, con los santos católicos. ${ }^{34}$

${ }^{31}$ Juana Elbein Dos Santos y Deoscoredes M. Dos Santos, refiriéndose al sistema místico y las prácticas religiosas heredadas de los africanos, señalaban que los grupos hegemónicos las denominaban despectivamente magia, superstición, brujería, fetichismo, superchería, lo cual constituía una manifestación de actitudes culturales valorativas que les negaba la categoría religiosa (104).

${ }^{32}$ Según Brown, esa influencia se extiende también a la teosofía y a los rosacruces (42).

${ }^{33}$ Los orixás son deidades intermediarias energéticas que participan en la vida de los hombres y los ayudan a solucionar situaciones problemáticas. Están por debajo del Dios Creador Supremo, Olorum, quien se mantiene alejado del mundo cotidiano.

${ }^{34}$ Oxalá, el orixá supremo, se sincretiza con Jesucristo; Yemanjá, orixá de la armonía, con la Virgen María o Stella Maris; Ogún, orixá de la guerra y la demanda, con San Jorge o San Antonio; Xangó, orixá de la justicia, con San Gerónimo o San Juan Bautista; Oxosse, orixá de las enfermedades, con San Sebastián. 
Del kardecismo, Umbanda adoptó el espiritismo, la incorporación y la reencarnación. ${ }^{35}$ Del amerindio, llegó a asimilar la creencia en los espíritus de los antepasados, los caboclos, y a compartir el amor y la veneración por las fuerzas de la naturaleza. Del islámico, tomó algunos aspectos rituales y de vestimenta. Mientras que del hinduísta y del budista, adoptó la meditación, el espiritualismo y el misticismo.

\section{COSMOVISIÓN AFRICANA}

Bajo una aparente diversidad cultural los varios grupos africanos que llegaron a América compartían principios provenientes de ancianos orígenes con similitudes en la gramática cultural. Todas las religiones afro-americanas mantuvieron casi intactos el principio de su propia identidad y una esencia mítica, ritual y ética, originada de culturas ricas en espiritualidad y tradición (Moro y Ramírez 8). Se pueden identificar núcleos filosóficos, espirituales y religiosos compartidos que configuran una cosmovisión africana esencial, imbuída de la presencia mágica de lo sobrenatural. ${ }^{36}$

La cosmovisión de las religiones africanas vincula a los hombres con los espíritus de los muertos y la naturaleza proyectando un vitalismo, panteísmo y animismo esenciales. Como Jorge Castellanos e Isabel Castellanos observaran respecto a las religiones afrocubanas, lo que caracteriza a las religiones afro-brasileñas, es la riqueza y la heterogeneidad de hierofanías. ${ }^{37}$ Para estas religiones "todo es sagrado: el cielo, la tierra, el sol y la luna, las aguas y las piedras... Todo objeto tiene un costado material y otro numinoso. Pero lo espiritual lo domina todo. La vida cotidiana consiste en un contacto constante con lo sagrado...." (271) Todo el universo - la naturaleza, los seres humanos, los ancestros, los orixás - es habitado por una energía o fuerza primordial que lo dota de espíritu y voluntad y que busca orden, equilibrio y armonía cósmica (Olaso 9). Cada orixá habita un elemento de la naturaleza. Al animar la naturaleza, los espíritus le dan consciencia y la invisten de un carácter sagrado. De modo que cada punto en el espacio natural puede ser un santuario.

Los orixás, los pretos velhos, espíritus de los negros viejos que fueron esclavos, los antepasados muertos e incluso los espíritus de la naturaleza responden y guían las acciones de los vivos con diferentes signos que son interpretados por la adivinación. Por otra parte,

\footnotetext{
${ }^{35}$ Nos referimos a la teoría de la reencarnación de Allan Kardec del siglo XIX.

${ }^{36}$ Sobre la cosmovisión africana, véanse: Santería from Africa to the New World: The Dead Sell Memories, de George Brandon; "Resistencia cultural: la religión", de María Eugenia Castillo de Amstrong; The Birth of African-American Culture: An Anthropological Perspective, de Sidney W. Mintz y Richard Price (45); Iemanjá, la diosa del mar, y Los secretos de la UMBANDA, de Ettore Pierri; "Antropóloga analiza Umbanda", de Sonia Romero; Myth, Literature and the African World, de Wole Soyinka (37-60); y Las claves mágicas de América. (Raza, clase y cultura), de Manuel Zapata Olivella.

${ }^{37}$ Jorge e Isabel Castellanos adoptan el término de Mircea Elíade entendiendo por hierofanía [c]ada una de las manifestaciones de lo sagrado, cada uno de los innumerables vehículos que lo sagrado utiliza para expresarse en la mente de los creyentes[...] Todo aquello con que el hombre ha entrado en contacto[...] manipulado, sentido o amado puede convertirse en una hierofanía" (271).
} 
se les rinde culto a los muertos quienes encarnan la moral colectiva y tienen un papel activo entre los vivos. ${ }^{38}$

Un aspecto esencial en los rituales afro-brasileños es la incorporación. Durante un ritual deslumbrante que crea un ambiente extraordinario de múltiples experiencias sensoriales con aromas de inciencios y hierbas, siguiendo un ritmo mántrico casi hipnótico de canciones, tambores y danzas, los sacerdotes umbandistas, el pai o la mae de santo, acompañados de otros iniciados invocan a sus espíritus protectores. El espíritu baja y posee el cuerpo del participante quien, en un trance, se transforma y transmite el mensaje de ese espíritu. ${ }^{39}$ Se trata de un rito de pasaje de experiencias del universo consciente hacia la otredad del inconsciente. Los adeptos acceden así a un intangible universo espiritual y participan directamente de una experiencia dionisíaca progresiva de acceso y absorción de esencias místicas. Las ceremonias están condicionadas a la "vibración" de la sesión y de los participantes.

En pos de la armonía continua en la relación hombre/naturaleza, Umbanda promueve una dinámica de mutuo apoyo, de solidaridad humana y de caridad que atrae a sus templos adeptos de toda la gama social, incluso la más privilegiada, aunque sus fieles practicantes vienen mayoritariamente de sectores de la clase media pauperizada y de los desocupados y subempleados de los cinturones de la ciudad. Se trata de una religión igualitaria que no admite diferencias sociales dentro del terreiro y que potencia nuevas solidaridades (Brown 36-51). En una de sus primeras incorporaciones, el fundador de Umbanda, Zelio de Moraes proclamó: "Umbanda será una religión que hablará a los humildes simbolizando la igualdad que debe existir en todos los hermanos encarnados y desencarnados" (Saidenberg 10). Umbanda predica la práctica del bien con una filosofía de paz, fraternidad humanitaria y armonía que en su aspecto totalizador elabora y proyecta principios de conservación y defensa del medio ambiente llegando a autodesignarse la religión de conciencia más ecologista (Leirós 6).

\section{EXPANSIÓN DE UMBANDA}

El ingreso y adopción de las religiones afro-brasileñas en Uruguay es un fenómeno inusitado. Como los esclavos africanos que entraran, - y luego permanecieran en el Uruguay-, al territorio por la porosa frontera uruguayo-brasileña, la africanía religiosa contemporánea ingresó por la misma ruta. La penetración se dio a partir de los años 40 y 50 por las ciudades brasileñas de la frontera y ha continuado crecientemente hasta hoy día.

El incremento de estas religiones neo-mágicas carece de precedentes en la cultura uruguaya. En la actualidad Umbanda representa la segunda fuerza religiosa del país, llegando a cifras muy próximas a la hasta ahora indiscutida religión mayoritaria, el catolicismo (Bayce, "Cultos afro-brasileños" 10). Nominalmente la población uruguaya es católica, aunque sólo una ínfima minoría asiste a la iglesia con regularidad y toma los

\footnotetext{
${ }^{38}$ Véanse: "Otra vida en esta vida," de Mauro Estévez, y Umbanda, de María I. Pallavicino (25-59).

${ }^{39}$ Según el Pai de Ayala, a diferencia del kardecismo que por la incorporación recibía espíritus de personalidades socialmente notables, Umbanda recibe espíritus de caboclos o pretos velhos (Salles y Ramos 10).
} 
sacramentos. ${ }^{40}$ La iglesia católica se ha desvigorizado y ha perdido su monopolio y hegemonía religiosa sin por ello eclipsar su impronta en el ethos uruguayo. ${ }^{41}$

En conjunción con el avance de otras religiones esotéricas, orientalistas, pentecostales protestantes, así como con otras prácticas religiosas populares - el Señor de la Paciencia, la Virgen de la Gruta de Lourdes, San Cono, San Benito, San Pancracio, el florecimiento de las religiones afro-brasileñas constituye un síntoma de cambios socio-culturales en la espiritualidad. El Uruguay no sólo ha sido y es un país laico sino también anticlerical, donde se ha cultivado una cultura de descreimiento teñida de un agudo excepticismo que, trivializando la fe, la devoción religiosa y sus prácticas, raya en el cinismo. ${ }^{42}$ Las ideas liberales y positivistas del siglo XIX fueron propagadas en el Uruguay ${ }^{43}$ y tomaron vuelo con la prédica ideológica del presidente José Batlle y Ordóñez. ${ }^{44}$ Con acendrado liberalismo y anticlericalismo, Batlle abogó por el laicismo y la secularización total del estado desde principios del siglo XX logrando exiliar la religión al espacio privado.

Es sorprendente que, en una sociedad con un habitus religioso ${ }^{45}$ marcado por la impronta del positivismo liberal, de tibia religiosidad y de antigua tradición racionalista y laica como la uruguaya, se hayan empezado a propagar las religiones afro-brasileñas. Tanto en Brasil como luego en Uruguay, inicialmente esas religiones eran desdeñadas y demonizadas. Por su orientación totalmente ajena al racionalismo y asociada con la magia, ${ }^{46}$ eran consideradas un atentado bárbaro y depravado contra la civilización europea y la

\footnotetext{
${ }^{40}$ Hace tres décadas, el $80 \%$ de la población se declaraba católica. Hoy en día, sólamente el $58 \%$.

${ }^{41}$ Un análisis de la religiosidad contemporánea en Uruguay se encontrará en "La nueva filosofía religiosa uruguaya", de Julio C. Elizaga, y, sobre la proliferación de cultos y sectas, en "Uruguay hoy: La explicable explosión de religiones y sectas", de Rafael Bayce.

${ }^{42}$ Para un estudio sobre el descreimiento y la trivialización de la religión, véase: The Culture of Disbelief: How American Law and Politics Trivialize Religious Devotion, de Stephen L. Carter.

${ }^{43}$ La primera constitución de la República (1830) proclamaba al catolicismo apostólico romano la religión oficial del estado. Sin embargo en 1875, la legislación uruguaya comenzó la secularización cuando el Código Civil dictó la separación del Registro Civil de la Iglesia Católica. Tal secularización quedó inscrita en la constitución de 1917 con la separación total de la iglesia y el estado.

${ }^{44}$ Batlle tuvo dos ciclos presidenciales: 1903-1907 y 1911-1915.

${ }^{45}$ Según Pierre Bourdieu, en "Legitimation and Structured Interests in Weber's Sociology of Religion," la religión provee a sus practicantes con un habitus religioso, una disposición interna perdurable, un esquema para actuar y pensar de acuerdo a los principios de una quasi-sistemática visión del mundo y de la existencia humana.

${ }^{46}$ Pierre Bourdieu distingue entre el interés religioso y el mágico. Originalmente, la magia se daba en sociedades primitivas. Se halla en la raíz de la religión de sociedades más complejas. El interés mágico es de carácter esencialmente parcial e inmediato y se da principalmente entre clases sociales populares, en sociedades rurales donde los individuos, poco orientados hacia la sistematización racional están íntimamente ligados a la naturaleza y dependen del acontecer natural. Bourdieu sostiene que a mayor tradición campesina ha de darse mayor incidencia de religiones mágicas. Por otra parte las poblaciones urbanas, en general, se inclinan hacia la racionalización. En contraste con el carácter temporal del trabajo agrícola que, inherentemente, está en contacto y expuesto a las fuerzas tangibles, inesperadas e incontrolables de la naturaleza, el burgués, desprendido del entorno inmediato y del contacto directo con la naturaleza y dependiendo para su sustento de un trabajo continuo y racional, transforma lo concerniente a los fenómenos naturales en un problema intelectual (Bourdieu 122-124).
} 
moralidad pública y sólo se practicaban clandestinamente en las periferias sociales. El cuestionamiento y la explicación del arraigo de estas religiones en el Uruguay han motivado encuestas, entrevistas y múltiples estudios académicos.

De acuerdo al Dr. Roberto Campos, los adeptos acuden al terreiro principalmente para hacer consultas acuciados por problemas del aquí y el ahora, situaciones personales, laborales, económicas, sentimentales y de salud que no han podido solucionar por otras vías seculares (Fernández 14). El poder de invocar las fuerzas sobrenaturales de los orixás para actuar rápida y mágicamente es el principal atractivo de Umbanda, lo cual por otra parte constituye una carencia del catolicismo. La promesa de las religiones cristianas de recompensa por los sufrimientos en el más allá, no alcanza para aliviar ni superar sufrimientos, privaciones ni penurias en este mundo. El uruguayo ya no espera sacrificar hoy para disfrutar en el mañana de un más allá dudoso e incierto. ${ }^{47} \mathrm{La}$ insuficiencia de los parámetros lógicos para satisfacer deseos y necesidades cotidianas, ha desencadenado una reacción contra los sistemas y cosmovisiones racionales eurocéntricos. Los cultos afrobrasileños ofrecen con su magia una nueva esperanza, una respuesta a necesidades inmediatas, con lo cual atrae muchos adeptos. En pos de esa esperanza, la gente recurre a alternativas sobrenaturales. Regresa a cultos, rituales y ofrendas mágicas, produciendo un "retorno de los brujos", afirma Bayce en "Uruguay hoy: La explicable explosión de religiones y sectas" (7-10). Desde el interior de un proceso que inicialmente fuera de secularización positiva en el cual la magia/tabú le cedió el paso a la religión/pecado, y ambos a la ciencia, el uruguayo se ha desencantado respecto del racionalismo positivista y la cosmovisión secular materialista, pero ha vuelto a reencantarse a partir de su propia dinámica de desencantamiento (Bayce "Uruguay" 6).

Iniciados por pais y maes de santo umbandistas de Porto Alegre que viajaban regularmente a Montevideo así como por los pais y maes de santo uruguayos que iban a Brasil para continuar con su formación religiosa, en la década de los sesenta, empezaron a aparecer en la periferia urbana montevideana terreiros muy pequeños y modestos. Durante los setenta comenzó un lento proceso de expansión (Pierri 31), constreñido por el Proceso militar (1973-1984) que acosó a estas religiones con prohibiciones de reuniones y allanamientos ilegales de sus templos. Sin embargo la expansión continuó clandestinamente.

En los ochenta estas religiones se fueron consolidando. El retorno a la democracia de 1984 encontró a Umbanda insertada irreversiblemente en la sociedad uruguaya (Pastor). ${ }^{48}$ Para fines de la década, la eclosión de Umbanda se aceleró. En 1983, en Montevideo había 700 templos afro-brasileños registrados ante las autoridades del estado y otros tantos clandestinos. En la actualidad, hay 2.000 terreiros y uno de cada seis uruguayos practica esta religión.

Comenzaron a presentarse y publicarse serios estudios académicos sobre Umbanda que iban profundizando en el tema, a la vez que ubicaban su significación en el contexto uruguayo. Continuaron actos públicos, conferencias, cursos y seminarios. En 1988, se realizó el Primer Congreso de Caciques y Jefes Umbandistas donde los antropólogos

\footnotetext{
${ }^{47}$ Según Felipe Arocena, tal situación es el motivo que ha llevado a algunas iglesias cristianas a actualizar sus rituales para hacerlos más adecuados a la vida y a las demandas cotidianas (9).

${ }^{48}$ Appratto de acuerdo a cita de Pastor en "¿Quién le teme a los Umbandistas?"
} 
declararon públicamente que Umbanda no era una secta sino una religión (Salinas y Porzecanski 6-7).

Auspiciado por el Ministerio de Turismo y la Intendencia de Montevideo, en enero de 1994, se realizó en Montevideo un Congreso Internacional de la Religión Afro-Umbandista, con delegados del Brasil, Argentina, México y Nigeria, y la adhesión diplomática de Cuba y Brasil. Concurrieron dirigentes políticos y participaron destacados cientistas sociales uruguayos. Allí se propuso fundar una Federación Internacional para codificar, institucionalizar y defender los principios religiosos y representar orgánicamente las religiones afro-americanas, iniciativa que aún no ha cristalizado a nivel internacional ni nacional.

Culminando largos esfuerzos, el dos de febrero de ese mismo año, se inauguró el monumento a Yemanyá en una rambla céntrica de Montevideo. Este acto convocó un amplio público que contó con profesionales y personalidades políticas notorias. Esa celebración se repite anualmente con un público crecientemente multitudinario e internacional, y se ha ido extendiendo de Montevideo a otras playas del país. ${ }^{49}$

Una vez recuperada la democracia liberal, Umbanda entró a ganar espacios públicos con gran poder de convocatoria. Apuntando hacia la divulgación, la consolidación y la unificación de la religión así como la documentación de los temas que preocupan a Umbanda y a sus líderes espirituales, empezó a aparecer la prensa umbandista: Nuestra Umbanda ${ }^{50}$ Quimbanda Palmares y Atabaque. También se organizaron programas de difusión radial y televisiva, proyecciones de películas y mesas redondas.

La expansión de Umbanda escaló niveles sin precedentes. Muchos individuos con fines comerciales y sin escrúpulos ni formación ni base doctrinal empezaron a establecer templos donde mercenariamente desvirtuaban los fundamentos de la religión. Surgieron varias iniciativas para dar coherencia a la religión, renovar la doctrina y recuperar la autenticidad confrontando la corrupción, el engaño y la mistificación. "La Corriente de Plata", fundada en 1987, sentó como uno de sus objetivos detener e impedir la corrupción de la acción religiosa.

Los órganos de la prensa escrita, oral y visual, empezaron a ocuparse del tema y han llegado a darle una atención y difusión sin precedentes. Esa conquista de nuevos espacios públicos junto con la iniciativa de formar una federación constituyen un esfuerzo por salir de los márgenes, una búsqueda de reconocimiento socio-cultural, de legitimación y de control social. A la vez, representa un empuje hacia la racionalización de Umbanda. Esfuerzos aparentemente justificados pero que inevitablemente tienden a limitar la flexibilidad inherente a esta religión mientras que la hace más vulnerable a influencias culturales hegemónicas orientándola hacia un mayor blanqueamiento y burocratización.

\footnotetext{
${ }^{49}$ En 1998, de casi dos millones de habitantes en Montevideo, 26\% de los montevideanos declararon que asistirían a esa celebración, en una encuesta auspiciada por el periódico El País del $1^{\circ}$ de febrero de ese año. Por supuesto, ello no significa necesariamente que todos los asistentes fueran umbandistas, pues se debe estimar que entre ellos hay un porcentaje de curiosos.

${ }^{50}$ Este periódico, abierto a todo tipo de consulta incluso jurídica, ha tenido dos breves épocas, en 1988 primero, luego en 1994, y ahora se dispone a iniciar una tercera.
} 
De acuerdo a mi investigación de campo de junio y julio de 1998, es evidente que en Uruguay a consecuencia de la rivalidad y competencia entre los líderes religiosos y diversos grupos umbandistas, hay luchas intestinas por la validación y expansión de la religión. El arduo camino de Umbanda desde la clandestinidad, la alteridad y el estigma, hacia el reconocimiento, la legimatimación y la afirmación de su identidad, está plagado de división y fragmentación, de luchas por el poder y el monopolio del control de las prácticas religiosas. ${ }^{51}$

En otro nivel, Umbanda está experimentando una gradual transformación. Hasta 1985, el discurso religioso se limitaba a la conservación y la reproducción del ritual sin cambios tal como había sido recibido del Brasil (Salinas/Porzecanski). Una vez terminado el proceso dictatorial y con mayor independencia, la religión comenzó a proyectarse más allá del reflejo de las prácticas brasileñas. Con iniciativas de renovación y de autorreflexión, se empezó a promover el análisis y el estudio de la religión con cursos, mesas redondas y publicaciones antropológicas y sociológicas.

Continuando con un proceso de hibridación cultural que la ha marcado desde sus orígenes, en Uruguay Umbanda sigue reelaborando liturgias y transformando nociones religiosas heredadas (Salinas/ Porzacanski). Los líderes religiosos han entrado en contacto con la Umbanda del exterior, incluso con sacerdotes de Nigeria: un pai de santo montevideano fue a Ifé, Nigeria, y de allí un representante fue a visitar los templos y los fieles umbandistas de Montevideo. Además, algunos líderes religiosos umbandistas han empezado a tomar iniciativas hacia la purgación del sincretismo con el catolicismo, la religión dominante, separando el panteón yoruba del cristiano, aunque no así respecto a los elementos sincretizados de otras culturas no hegemónicas. Ese retorno a las raíces africanas se manifiesta también en la parafernalia de los templos, la música, las canciones y la coreografía de las danzas. Incluso se han empezado a dar clases de yoruba, idioma que, en muchos templos, se emplea como lenguaje de culto entretejido con el portugués y también el español. Asimismo, varios adeptos y sacerdotes, han manifestado interés en lograr producir rituales auténticamente afro-uruguayos. En algunos terreiros, se incluyen ya en los rituales la música y el tamboril afro-uruguayo. ${ }^{52}$

Al entrar en contacto con el contexto uruguayo, Umbanda, paulatinamente, ha empezado a experimentar cambios que fortalecen su identidad religiosa. Además, se han difundido y ofrecido alternativas de reelaboración cultural que potencian la reorganización y alteración del marco conceptual dentro del cual se determina y legitima el poder. De ese modo Umbanda ha inscrito un gestus socio-político que la proyecta como práctica contracultural de resistencia. ${ }^{53} \mathrm{Al}$ insertar alternativas religiosas heterogéneas, Umbanda

\footnotetext{
${ }^{51}$ Según Bourdieu, al rivalizar por el poder religioso se compite por el monopolio del legítimo ejercicio del poder de modificar de modo duradero la práctica y la cosmovisión de los concurrentes a templos religiosos (126-27). La legitimidad se logra como resultado de luchas intestinas por el monopolio del ejercicio aceptado del poder religioso.

${ }_{52}$ El Pai Roberto de Xangó, en entrevista personal de julio de 1998, y Juan Antonio Machado, en “¿Una religión afro-uruguaya?” abogan por la recreación de Umbanda adoptando elementos culturales uruguayos.

${ }^{53}$ Para una conceptualización de la religión como resistencia, véase "Signs Taken for Wonders: Questions of Ambivalence and Authority under a Tree Outside New Delhi, May 1817," de Homi
} 
desmantela las bases rígidas de la legitimidad, la autoridad y la universalidad del catolicismo dominante y homogeneizador. Sin sustituir el foco de un centro por otro, se proyecta más allá de la dicotomía centro/margen para desarticular críticamente la polarización maniquea y las nociones epistemológicas y religiosas heredadas (Ashcroft 104).

Así como la civilización greco-romana y también la colonia española se difundieron entre otros factores, gracias a la religión, la diáspora africana recuperó, desarrolló y reelaboró sus propias tradiciones culturales por medio de este mismo vehículo. ${ }^{54}$ Todas las prácticas culturales del africano hasta las más profanas están imbuídas de la religión, elemento fundamental de cohesión cultural, que ha permitidoe incentivado "el reagrupamiento institucionalizado de los africanos y sus descendientes" (Dos Santos 114). Propiciada por elementos culturales subyacentes, Umbanda ha logrado activar en Uruguay un componente africano desplazado y sumergido a la vez que ha rehabilitado una cultura familiar. ${ }^{55} \mathrm{~A}$ diferencia del candombe que ha reafricanizado la cultura uruguaya desde su fundación, desde sus propias raíces históricas, las religiones afro-brasileñas la han fertilizado contemporáneamente desde el exterior para recuperar por entre los intersticios una africanía subyacente.

Interesa señalar que la mayoría de los asistentes a los terreiros tanto como los pais y las maes de santo son blancos, hecho que provoca cierto malestar entre algunos afrouruguayos por lo que perciben como apropiación y usurpamiento de un legado cultural africano en manos de caucásicos. Si bien es evidente que se trata de un blanqueamiento de Umbanda, aunque desde su concepción ésta ha sido una religión blanqueada, no se puede ignorar que este fenómeno de hibridación no es unilateral.

La africanía a través de la magia de Umbanda, al principio clandestinamente y sin un plan previo, ha invadido el territorio cultural del Uruguay. Desde zonas culturalmente fronterizas, Umbanda, ha traducido y proyectado su cosmovisión africana sobre y por debajo de los códigos culturales uruguayos. Con sus cosmologías y su manera de comprender y enfrentar el universo, Umbanda se ha infiltrado y propagado con ímpetu por toda la gama social. La ha impregnado, creando nuevos espacios y formas de poder, de saber y de ser. Como agente de hibridación, esta religión subalterna de origen "espúreo" ha inscrito una impronta de africanía, una reterritorialización/neo-africanización que afecta profundamente la cultura uruguaya resultando en transformaciones de espiritualidad y cosmovisión de alcances futuros imprevisibles.

Agradezco al Profesor Alberto Britos Serrrat el invalorable material periodístico y bibliográfico que me proporcionó para este estudio así como al Dr. Roberto Campos y a la antropóloga Mónica Olaso la información sobre las prácticas umbandistas en Uruguay.

Bhabha (181). Para una estimación de Umbanda como resistencia, véase "Resistencia cultural: la religión," de María Eugenia Castillo de Amstrong.

${ }^{54}$ Para una lúcida conceptualización de este paralelo en el contexto cubano, véase el capítulo I, de Afro-Cuban Religious Experience. Cultural Reflections in Narrative, de Matibag.

${ }^{55}$ Para una perspectiva profunda del retorno de una cultura reprimida, véase: "Tracing Hibridity in Theory," de Papastergiadis (273). 


\section{Bibliografia}

Appiah, Kwame Anthony. "Is the Post- in Postmodernism the Post- In Postconial?" Critical Inquiry 17 (Winter 1991): 336-57.

Arocena, Felipe. "Iemanjá y los cultos afro-brasileños". El País (Montevideo, 1 de febrero de 1998): 9.

Ashcroft, Bill, Gareth Griffiths y Helen Tiffin (eds.). The Empire Writes Back: Theory and Practice in Post-Colonial Literature. Nueva York: Routledge, 1989.

Bayce, Rafael. "Cultos afro-brasileños en Uruguay: El éxito de los pai de santo". Brecha (Montevideo, 24 de abril de 1992): 10.

"Uruguay hoy: La explicable explosión de religiones y sectas". Cuadernos de Marcha. Tercera época. Año VII (febrero de 1992): 2-14.

Bhabha, Homi. "Signs Taken for Wonders: Questions of Ambivalence and Authority under a Tree Outside New Delhi, May 1817'. 'Race', Writing, and Difference. Henry Louis Gates, Jr. Chicago: University of Chicago Press, 1985. 163-184.

Bottaro, Marcelino. "Rituals and Candombes". Negro. An Anthology. Nancy Cunard, ed. Nueva York: Negro University Press, 1934. 519-22.

Bourdieu, Pierre. "Legitimation and Structured Interests in Weber's Sociology of Religion". Chris Turner, trad. Max Weber, Rationality and Modernity. Scott Lash y Sam Whimster. Winchester, MA: Allen \& Unwin, 1987.

Bourdieu, Pierre y Loïc J.D. Wacquant. Respuestas: Por una antropología reflexiva. Hélene Levesque Dion, trad. México, DF: Grijalbo, 1995.

Brandon, George. Santeria from Africa to the Western World: Dead Sell Memories. Bloomington: Indiana University Press, 1993.

Britos Serrat, Alberto (ed.). Antología de poetas negros uruguayos. Vol. I. Montevideo: Ediciones Mundo Afro, 1990.

Antología de poetas negros uruguayos. Vol. II. Montevideo: Ediciones Mundo Afro, 1997.

Brown, Diane DeG. Umbanda: Religion and Politics in Urban Brazil. Ann Arbor: UMI Research Press, 1986.

Carter, Stephen L. The Culture of Disbelief: How American Law and Politics Trivialize Religious Devotion. Nueva York: Basic Books, Harper Collins, 1973.

Castellanos, Jorge e Isabel Castellanos. Cultura Afrocubana. vol. 3. Las religiones y las lenguas. Miami: Ediciones Universal, 1992.

Castillo de Amstrong, María Eugenia. "Resistencia cultural: La religión, fuerza de cohesión de los esclavos". Nuestra Umbanda. [Montevideo] Segunda Epoca. 1. 6: 12.

Certeau, Michel de. The Practice of Everyday Life. Berkeley: University of California Press, 1984.

Cordones-Cook, Juanamaría. ¿Teatro negro uruguayo? Texto y contexto del teatro afrouruguayo de Andrés Castillo. Montevideo: Editorial Graffiti, 1996.

"Cuerpo, mente y espíritu: Dioses, salud y enfermedad". Nuestra Umbanda. [Montevideo] Segunda Epoca. 1. 9: 6. s.a.

Dos Santos, Juana Elbein y Deoscoredes M. Dos Santos. "Religión y cultura negra". Africa en América Latina. Manuel Moreno Fraginals, relator. México: Siglo Veintiuno, 1977. 103-128. 
Elizaga, Julio C. "La nueva filosofía religiosa uruguaya". Análisis \& Desafios Año 1/8 (Montevideo, mayo 1992): 19-21.

Estévez, Mauro. "Otra vida en esta vida". Nuestra Umbanda Segunda Epoca. Año 1/9 [Montevideo]: s.p.

Fanon, Franz. Black Skin, White Masks. Nueva York: Grove Press, 1967. The Wretched of the Earth. Nueva York: Grove Press, 1968.

Fernández, Diego. "Con Roberto Campos: Los cultos afro dan soluciones aquí y ahora". Brecha 4 (Montevideo, febrero 1994): 14.

JanMohamed, Abdul R. "The Economy of the Manichean Allegory: The Function of Racial

Difference in Colonialist Literature". 'Race', Writing, and Difference. Henry Louis Gates, Jr. Chicago: The University of Chicago Press, 1985.

Manichean Aesthetics: The Politics of Literature in Colonial Africa. Amherst: University of Massachusetts Press, 1983.

Leirós, José María. “Afroumbandismo: Religión de esencia ecologista". Nuestra Umbanda. Segunda Epoca. Año 2/1 [Montevideo]: 6.

Lotman, Juri. M. The Universe of the Mind. A. Shukman, trad. Londres: I.B. Tauris, 1991. Machado, Juan Pedro. “¿Una religión afro-uruguaya?” Nuestra Umbanda. Segunda Epoca. 1 [Montevideo]: 12.

Matibag, Eugenio. Afro-Cuban Religious Experience: Cultural Reflections in Narrative. Gainsville: University Press of Florida, 1996.

Mintz, Sidney W. y Richard Price. The Birth of African-American Culture: An Anthropological Perspective. Boston: Beacon Press, 1992.

Moraña, Mabel. Memorias de la generación fantasma. Montevideo: Monte Sexto, 1988. Morejón, Nancy. Nación y mestizaje en Nicolás Guillén. La Habana: Ediciones Unión, 1982.

Moreno Fraginals, Manuel (relator). Africa en América Latina. México: Siglo Veintiuno, 1977.

“Aportes culturales y deculturación”. África en América Latina. México: Siglo Veintiuno, 1977.

Moro, América y Mercedes Ramírez. LA MACUMBA y otros cultos afro-brasileños en Montevideo. Montevideo: Ediciones de la Banda Oriental, 1981.

Olaso, Mónica. "Relaciones humanas dentro del terreiro. La casa de Roberto de Oxalá". Ponencia. Congreso Internacional de la Religión Afro-Umbandista. Enero 30,1994. Montevideo.

Olivera Chirimini, Tomás y Juan Antonio Varese. El candombe: Sus orígenes, su historia, sus proyecciones. Montevideo: Ediciones El Galeón, 1992.

Ortiz, Fernando. Contrapunteo cubano del tabaco y el azúcar. Prólogo de Bronislaw Malinowski. Barcelona: Editorial Ariel, 1973.

de Oxalá, Armando. "Brujos, científicos, medicina tradicional y falsos profetas". Nuestra Umbanda. Segunda Epoca. 1/7 [Montevideo]: 4. s.a.

Papastergiadis, Nikos. "Tracing Hibridity in Theory." Debating Cultural Hibridity: MultiCultural Identities and the Politics of Anti-Racism. Pnina Werbner y Tariq Modood, eds. New Jersey: Zed Books, 1997. 257-81.

Pastor, Gabriel. “¿Quién le teme a los umbandistas?” Nuestra Umbanda. Segunda Epoca. 1/6 [Montevideo]: 12. 
Pierri, Ettore. Iemanjá, la diosa del mar. Montevideo: Ediciones La República, 1994. Los secretos de la UMBANDA. Montevideo: Ediciones La República, 1994.

Porzecanski, Teresa. Curanderos y canibales: Ensayos antropológicos sobre charrúas, chamanes, adivinos y románticos ( $2^{a}$ edición corregida y aumentada). Montevideo: Luis A. Retta Libros, 1993.

Rama, Ángel. Transculturación narrativa en América Latina. México: Siglo XXI, 1985.

Rama, Carlos M. Los afro-urugayos. Montevideo: Siglo Ilustrado, 1967.

Romero, Sonia. "Antropóloga analiza a la umbanda". Nuestra Umbanda. Segunda Epoca. $1 / 8$ [Montevideo]: 15. s.p.

Rosaldo, Renato. "Ideology, Place and People Without Culture". Cultural Anthropology. 3 (February 1988): 77-80.

Rossi, Vicente. Cosas de negros. Buenos Aires: Hachette, 1958.

Saidenberg, Theresa. "Cómo surgió la Umbanda". Atabaque. 1/1 [Montevideo]: 10. s.f. Salinas, Nelly y Teresa Porzecanski. "Rituales afrouruguayos: Una revisión histórica. Afirmación creciente de la africanidad ingrediente clave de un proceso que continúa vigente." Nuestra Umbanda. Segunda Epoca. Año 2. [Montevideo]: 6-7.

Salles, Gonzalo y Valeria Ramos. Religiones afro-brasileñas en el Uruguay. s.f. s.e.

Soyinka, Wole. Myth, Literature and the African World. Nueva York: Cambridge University Press, 1976.

Suárez Peña, Lino. Apuntes y datos referentes a la raza negra a los comienzos de su vida en esta parte del Plata. Montevideo: Museo Lavalleja, 1923.

Trigo, Abril. "Candombe and the Reterritorialization of Culture". Callaloo. 16-3 (1993): 716-28.

Young, Robert J.C. Colonial Desire: Hybridity, Culture and Race. Nueva York: Routledge, 1995.

Zapata Olivella, Manuel. Las claves mágicas de América.(Raza, clase y cultura). Bogotá: Plaza y Janés, 1989. 
